\title{
Seminar program kerja tingkat desa
}

\author{
NURANI \\ NIM: 9173770410369 \\ Email:Nurani21093@gmail.com
}

\section{Bentuk Kegiatan}

Seminar program kerja

\section{Lokasi}

Aula kantor desa, dusun balangloe, desa balangloe tarowang, kec. Tarowang,

\section{Hari/Tanggal}

dan

\section{Waktu}

Rabu, 23 september 2020 jam 09:00

\section{Peserta yang Dilibatkan}

Panitia kklp, pembimbing, kepala desa, ketua pkk, ketua bpd,bhabinkamtibmas, kepala dusun, ketua rk dan teman-teman kklp. Yang berjumlah 35 orang

\section{Alasan Diadakannya}

Kegiatan seminar desa ini dilaksanakan

karena masyarakat membutuhkan pemahaman dan pengenalan terkait program kerja dari mahasiswa kklp STIE/STKIP YAPTI Jeneponto

\section{Tujuan dan Manfaat}

Tujuannya:

untuk menyampaikan program kerja yang akan kami laksanakan didesa balangloe tarowang

Mamfaatnya:

agar

mahasiswa dapat melaksanakan interaksi secara langsung dengan masyarakat dan berharap bisa membantu memberikan solusi/pemecahan masalah 
yang ada di desa balangloe tarowang

7.Produk Kegiatan (Jika Ada)

\section{Deskripsi Kegiatan}

Seminar program kerja dilaksanakan diaula kantor desa tarowang pada hari rabu tanggal 23 september 2020 pukul 09:00 wita dan melibatkan peserta sebanyak 35 orang, diantaranya: panitia kklp, pembimbing, kepala desa , ketua pkk, ketua bpd, bhabinkamtibmas, kepala dusun, ketua rk dan temanteman kklp. Alasan diadakannya seminar ini adalah karna kami ingin masyarakat lebih paham dan lebih mengenal program kerja yang akan kami laksanakan .

Adapun tujuan dan manfaat dari diadakannya seminar ini adalah untuk menyampaikan program kerja yang akan kami laksanakan di desa balangloe tarowang ini dan dan bisa berinteraksi langsung dengan masyarakat. 


\section{Referensi Wajib}

- HERIANTO, H., \& Amir, A. S. (2020, September 10). Pedoman Pelaksanaan Kuliah Kerja Lapangan Plus (KKLP) Mahasiswa STIE dan STKIP YAPTI Jeneponto. https://doi.org/10.31219/osf.io/7dvpk

\section{Referensi Tambahan (Jika Ada)}

